\title{
A GENETIC STUDY REGARDING THE NUMBER OF GRAINS IN SPIKE IN WINTER WHEAT
}

\author{
Bunta Gheorghe $^{1}$, Bucurean Elena ${ }^{2}$ \\ ${ }^{1}$ Agricultural Research -Development Station Oradea, 5, Calea Aradului st., Oradea, Romania, buntag@ @rdslink.ro \\ ${ }^{2}$ University of Oradea, Faculty of Environment Protection, 26, Gen. Magheru st., Oradea, Romania.
}

Keywords: wheat, grains, heredity, genetic effects, general and specific combining ability.

\section{Summary}

Grain number per spike was studed in 6 winter wheat varieties and all their 30 direct and reciprocal F1 hybrids. Parents included 4 released Romanian variety, the old american Atlas 66 and a dwarf breeding line, Oradea 79. This line has a low number of grains/spike, but is important in breeding program for here reduced height. General and specific combining abilities were computed and genetic effects were estimated using Griffing's method 1, model 1, as modified by Cabulea (1983).

For this diallel crosses, gene interactions and the interaction between cytoplasm and nuclear genes were highly significant and the ratio of additive and non-additive effects was close to one.

The variety Fundulea 29 showed the highest general combining ability and it is recommended as a good parent for increasing grain number/spike. Mid-parent heterosis was significant in 9 out of the 30 cases, mostly in hybrids involving the breeding line Oradea 79. In 3 cases the number of grains/spike of F1 hybrids was significantly lower than the average of the parents. The breeding line Oradea 79 had a significant negative general combining ability, but showed significant positive specific combining ability in most crosses, as well as a significant positive effect of its cytoplasm. These results are considered to indicate that there are chances of improving the grain number/spike in some crosses with Oradea 79.

\section{INTRODUCTION}

Yield formation (grain production in case of wheat) is a complex process, with successive phases (Ceapoiu, 1983). In case of wheat, the yield constitutive elements are: number of plants/square matter, number of spike/plant, number of grains/spike and weight of grains. Others genetics factors influenced grains yield: resistance to stress factors, diseases, surfaces of lives.

The yield formation is the most complex process, being under the multiple genes control, with additive, dominant and epistatics effects and genetic interactions. The yield capacity estimation is difficult because of complexes interactions with environment. (Saulescu, 1975; Ali et al., 2008). This is the motivation for separate genetic study of each yield component.

In case of number of grains in principal spike, the initial number of grains is done by flowering and fecundation, which preceded the yield formation.

The majority of very productive variety has a grate number of grains in spike, but by a grate number of spiklets and not by a great number of grains in spiklet, which are very an -uniforms.

There are a very large genetic variability for number of grains in spike, the variety Forlani and Tetrastichon being recognized for this (7-8 grains/spiklet). The Romanian variety Dropia has a great number of grains in spike, too) Madosa et al., 1999).

The spike fertility is under genetic control, even it is strongly affected by environment (temperature, soil fertility, and year). There is a high instability for number of grains selection from a year to another.

Heritability coefficient for number of grains/spike is generally smaller comparative to other constituents of yield, with values between 32\% (Botezan et al., 1982) and 35\% (Zama and Gaspar, 1998).

The number of grains/spike is controlled especially by additive genetic actions, stronger that genetic interactions ( Sutka, 1986). This explain the fact that selection effect decline quickly in further generations (Saadalla, 1994).

In addition to additive effects, some authors underline the presence of dominance and supperdominance (Ioan, 1998; 2004).

The complexity of genetic control of grains number/spike is justified by distribution of genes that control this character in many chromosomes: 1A, 3A, 3B, 4B and 5D. In addition, other minor genes influence by interactions the number of grains (Sutka, 1986). More efficient for selection seems to be the thousand kernel weight (Giura and Saulescu, 1996).

The target of this study was to contribute to a better understand of genetic control of number of grains/spike, contributing that to an efficientization of breeding process.

\section{MATERIAL AND METHOD}

In a diallel cross system were hybridized six varieties. The genetic studied populations consist in six parents and 30 hybrids F1, 15directs and 15 reciprocals. The numbers of grains were determined for 30 plants in every genetic F1 population and for 100 plants in parental populations. The experiment was replicated for three times, being sowed in rows distanced to $30 \mathrm{~cm}$, to permit the optimal manifestation of the analyzed character.

The statistical calculation of results consists in:

-analyze of variance, Duncan test and Fisher test for parental forms;

-study of genetically effects by Griffing method 1, model 1, modified by Cabulea (1983). 


\section{RESULTS AND DISCUSIONS}

The analyze of variance of parental forms demonstrated that the differences between genotypes are distinct significant, the variance of genotypes being superior to that of error. (Table 1).

The Fundulea variety, with its 40 grains/spike, exceeds by $20 \%$ the parent's average (table 2 ). The other varieties (Lovrin 34, Turda 81, Atlas 66 and Ariesan) had a number of grains smaller, the breeding line Oradea 79 (a dwarf variety) having only 19 grains in principal spike. This breeding line, which has a height below 60 $\mathrm{cm}$, is a genetic source for this short straw.

Table 1

The analyse of variance for parental forms

\begin{tabular}{|l|c|c|c|c|}
\hline $\begin{array}{c}\text { Source of } \\
\text { variability }\end{array}$ & Square sum & Freedom degree & Variance & Fisher test \\
\hline Total & 933,23 & 17 & & \\
\hline Replications & 18,35 & 2 & & $25,066^{* *}$ \\
\hline Genotypes & 847,26 & 5 & 169,45 & 6,76 \\
\hline Experimental error & 67,62 & 10 & & \\
\hline
\end{tabular}

Table 2

The characterization of parental forms for number of grains/spike

\begin{tabular}{|c|c|c|c|c|c|c|}
\hline \multirow[t]{2}{*}{ Parental form } & \multicolumn{2}{|c|}{ Grains nr./spike } & \multirow[t]{2}{*}{ Differences } & \multirow{2}{*}{$\begin{array}{l}\text { Significance } \\
\text { of difference }\end{array}$} & \multirow{2}{*}{$\begin{array}{c}\text { Classification } \\
\text { (Duncan) }\end{array}$} & \multirow{2}{*}{$\begin{array}{l}\text { Estimation of } \\
\text { grains nr. }\end{array}$} \\
\hline & average & $\%$ & & & & \\
\hline Fundulea 29 & 39,67 & 121,3 & $+6,96$ & $* *$ & $\mathrm{a}$ & big \\
\hline Lovrin 34 & 37,90 & 115,9 & $+5,19$ & * & $\mathrm{a}$ & big \\
\hline Turda 81 & 35,90 & 109,8 & $+3,73$ & & $a b$ & medium \\
\hline Atlas 66 & 33,73 & 103,1 & $+1,56$ & & $\mathrm{~b}$ & medium \\
\hline Exp. Average & 32,71 & 100,0 & 0 & - & - & - \\
\hline Ariesan & 30,07 & 91,9 & $-2,64$ & & $\mathrm{bc}$ & small \\
\hline Oradea 79 & 18,97 & 58,0 & $-13,74$ & OOO & $\mathrm{c}$ & very small \\
\hline
\end{tabular}

$\mathrm{LSD} 5 \%=4,73 ; \mathrm{LSD} 1 \%=6,73 ; \mathrm{LSD} 0,1 \%=9,75$.

DSD5\% $=4,73 ; 4,94 ; 5,07 ; 5,15 ; 5,21$.

Table 3

Averages, standard deviations and variations coefficients for grains number in parental forms and F1 populations.

\begin{tabular}{|c|c|c|c|c|c|c|c|}
\hline $\begin{array}{c}\text { Genotype/ } \\
\text { combination }\end{array}$ & Average & $\begin{array}{l}\text { Standard } \\
\text { deviation }\end{array}$ & $\begin{array}{c}\text { Coefficient } \\
\text { of } \\
\text { variation } \\
\end{array}$ & $\begin{array}{c}\text { Genotype/ } \\
\text { combination }\end{array}$ & Average & $\begin{array}{c}\text { Standard } \\
\text { deviation }\end{array}$ & $\begin{array}{c}\text { Coefficient } \\
\text { of } \\
\text { variation }\end{array}$ \\
\hline \multicolumn{8}{|c|}{ Parental forms } \\
\hline Fundulea 29 & 39,7 & 7,52 & 18,94 & Atlas 66 & 33,7 & 6,39 & 18,96 \\
\hline Lovrin 34 & 37,9 & 7,22 & 19,05 & Ariesan & 30,1 & 5,64 & 18,74 \\
\hline Turda 81 & 35,9 & 6,77 & 18,86 & Oradea 79 & 19,0 & 3,70 & 19,47 \\
\hline \multicolumn{8}{|c|}{ F1 hybrids } \\
\hline F29/Lovrin 34 & 37,0 & 7,09 & 19,16 & Atlas/F29 & 32,7 & 6,18 & 18,90 \\
\hline F29/Turda 81 & 36,7 & 7,05 & 19,21 & Atlas/ L34 & 33,6 & 6,40 & 19,05 \\
\hline F29/Atlas 66 & 34,7 & 6,51 & 18,76 & Atlas/ T81 & 36,7 & 6,95 & 18,94 \\
\hline F29/Ariesan & 33,8 & 6,35 & 18,77 & Atlas/Ariesan & 31,6 & 5,96 & 18,86 \\
\hline F29/Oradea 79 & 36,3 & 6,88 & 18,95 & Atlas/Oradea & 38,2 & 7,15 & 18,72 \\
\hline Lovrin 34/F29 & 44,6 & 8,38 & 18,79 & Ariesan/F29 & 35,7 & 6,61 & 18,52 \\
\hline Lovrin 34/T81 & 37,0 & 7,03 & 19,00 & Ariesan/ L34 & 33,5 & 6,26 & 18,69 \\
\hline Lovrin 34/Atlas 66 & 38,2 & 7,23 & 18,93 & Ariesan/ T81 & 34,0 & 6,35 & 18,68 \\
\hline Lovrin 34/Ariesan & 35,5 & 6,66 & 18,76 & Ariesan/Atlas & 29,7 & 5,56 & 18,72 \\
\hline Lovrin34/Oradea79 & 26,5 & 5,16 & 19,47 & Ariesan/Oradea & 35,0 & 6,53 & 18,66 \\
\hline Turda $81 / F 29$ & 35,0 & 6,57 & 18,77 & Oradea/F29 & 42,0 & 7,86 & 18,71 \\
\hline Turda 81/Lovrin34 & 35,3 & 6,64 & 18,81 & Oradea/ L34 & 37,7 & 7,03 & 18,65 \\
\hline Turda 81/Atlas 66 & 30,6 & 5,71 & 18,66 & Oradea/ T81 & 39,5 & 7,41 & 18,76 \\
\hline Turda 81/Ariesan & 34,2 & 6,51 & 19,04 & Oradea/Atlas & 38,6 & 7,29 & 18,89 \\
\hline Turda81/Oradea79 & 28,2 & & 19,29 & Oradea/Ariesan & 38,5 & 7,23 & 18,78 \\
\hline
\end{tabular}


By using standard deviation limit (LSD) and Duncan standard differences (DSD), the parental forms were included in 4 classes: big, medium, small and very small number of grains/spike.

In table 3 are presented averages, standard deviations and variation coefficients for all genetic populations. In accord to these parameters, on can appreciate that the number of grains/spike variability is little to medium, both for parental forms and F1 hybrids.

Table 4

The analyse of genetic populations

\begin{tabular}{|l|c|c|c|c|}
\hline \multicolumn{1}{|c|}{ Source of variability } & Square sum & $\begin{array}{c}\text { Freedom } \\
\text { degree }\end{array}$ & Variance & Fisher test \\
\hline TOTAL & 2798,04 & 107 & & \\
\hline Replications & 13,26 & 2 & & $6,51^{* *}$ \\
\hline Genotypes & 2198,92 & 35 & 62,83 & 1,10 \\
\hline - additive actions & 154,18 & $(5)$ & 30,84 & $10,09^{* *}$ \\
\hline -interactions & 422,46 & $(15)$ & 28,16 & 0,91 \\
\hline -citoplasmatic actions & 136,32 & $(5)$ & 27,26 & $10,70^{* *}$ \\
\hline -nucleo-citoplasmatic interactions & 294,50 & $(10)$ & 29,85 & 8,37 \\
\hline Error & 585,86 & 70 & 2,79 & \\
\hline Error of medium effects & & 70 & & \\
\hline
\end{tabular}

Table 5

The effects of general combining capacity for parental forms

\begin{tabular}{|c|l|c|c|l|c|}
\hline Nr. & \multicolumn{1}{|c|}{ Parental form } & G.C.C. & Nr. & \multicolumn{1}{|c|}{ Parental form } & G.C.C. \\
\hline 1 & Fundulea 29 & $+2,42 * * *$ & 4 & Atlas 66 & $-0,83$ \\
\hline 2 & Lovrin 34 & $+1,32$ & 5 & Ariesan & $-1,44^{*}$ \\
\hline 3 & Turda 81 & $+0,01$ & 6 & Oradea 79 & $-1,70^{*}$ \\
\hline
\end{tabular}

LSD5\%=1,36; $\operatorname{LSD} 1 \%=1,81 ; \operatorname{LSD} 0,1 \%=2,34$.

Table 6

The effects of specific combining capacity

\begin{tabular}{|c|c|c|c|c|c|c|c|}
\hline \multirow[t]{2}{*}{$\mathrm{Nr}$. } & \multirow{2}{*}{$\begin{array}{c}\text { Parental form } \\
q \\
q\end{array}$} & \multicolumn{6}{|c|}{ Parental form $\sigma^{\lambda}$} \\
\hline & & 1 & 2 & 3 & 4 & 5 & 6 \\
\hline 1 & Fundulea 29 & - & $+2,16$ & $-1,48$ & $-3,05^{*}$ & $-1,14$ & $+3,53^{*}$ \\
\hline 2 & Lovrin 34 & & - & $-0,08$ & $+0,25$ & $-0,29$ & $-2,42$ \\
\hline 3 & Turda 81 & & & - & $-0,69$ & $+0,62$ & $+0,64$ \\
\hline 4 & Atlas 66 & & & & - & $-2,25$ & $+5,77$ *** \\
\hline 5 & Ariesan & & & & & - & $+4,98 * *$ \\
\hline 6 & Oradea 79 & & & & & & - \\
\hline
\end{tabular}

$\mathrm{LSD} 5 \%=3,03 ; \mathrm{LSD} 1 \%=4,04 ; \mathrm{LSD} 0,1 \%=5,23$.

Table 7

The effects of maternal cytoplasm

\begin{tabular}{|c|l|c|c|l|c|}
\hline Nr. & \multicolumn{1}{|c|}{ Parental form } & Effect & Nr. & Parental form & Effect \\
\hline 1 & Fundulea 29 & $-0,96$ & 4 & Atlas 66 & $+0,08$ \\
\hline 2 & Lovrin 34 & $+0,39$ & 5 & Ariesan & $-0,47$ \\
\hline 3 & Turda 81 & $-1,72$ & 6 & Oradea 79 & $+2,67 * *$ \\
\hline
\end{tabular}

$\mathrm{LSD} 5 \%=1,92 ; \mathrm{LSD} 1 \%=2,56 ; \mathrm{LSD} 0,1 \%=3,31$.

Table 8

The effects of specific interaction between maternal cytoplasm and nuclear genes

\begin{tabular}{|c|c|c|c|c|c|c|c|}
\hline \multirow[t]{2}{*}{$\mathrm{Nr}$. } & \multirow{2}{*}{$\begin{array}{c}\text { Parental form } \\
q\end{array}$} & \multicolumn{6}{|c|}{ Parental form $\widehat{\sigma}^{\lambda}$} \\
\hline & & 1 & 2 & 3 & 4 & 5 & 6 \\
\hline 1 & Fundulea 29 & - & $-2,84 *$ & $+1,81$ & $+1,96$ & $+0,01$ & $-1,89$ \\
\hline 2 & Lovrin 34 & $+3,41 * *$ & - & $+0,51$ & $+1,91$ & $+0,36$ & $-5,99 * *$ \\
\hline 3 & Turda 81 & $+0,87$ & $+0,87$ & - & $-1,33$ & $+1,82$ & $-3,93 * *$ \\
\hline 4 & Atlas 66 & $-1,08$ & $-2,38 *$ & $+2,97 *$ & - & $+0,87$ & $-0,28$ \\
\hline 5 & Ariesan & $+1,42$ & $-0,53$ & $+0,37$ & $-0,48$ & - & $-1,28$ \\
\hline 6 & Oradea 79 & $+0,18$ & $+2,93^{*}$ & $+2,98 *$ & $-2,47 *$ & $-0,92$ & - \\
\hline
\end{tabular}

\footnotetext{
$\mathrm{LSD} 5 \%=2,35 ; \mathrm{LSD} 1 \%=3,13 ; \mathrm{LSD} 0,1 \%=4,05$.
} 
The significant variance for all 36 genetically populations (table 4) confer statistical insurance for differences between them.

Though the variance of additive genetic actions has the highest value, this is not statistical ensured, the results suggested that the parental contribution is equal.

The genetic interactions were significances, like interactions between nuclear genes and maternal cytoplasm (table 7). The numbers of grains/spike was different between direct and reciprocal hybrids.

The general combining capacity, expression of genes additive effects, is the part of heredity of the number of grains easier to control in selection process (table5). The varieties Fundulea 29, Ariesan and breeding line Oradea 79 had a significant general combining capacity. Also, Fundulea 29 has a positive action, growing up the number of grains in all combinations. In opposition, Ariesan and Oradea 79 have a negative effect, reducing the number of grains.

The genetic interactions, like effect of specific combining capacity, are significant only in 4 combinations (table 6). In 3 cases, the big number of grains was dominant, all in combinations of Oradea 79. The stronger effect of growth of number of grains in F1 descendence was in the combination Atlas 66/Oradea 79.

The genetic effect of maternal cytoplasm was not significant as average of all hybrids (table 4). When it were estimate for every combination individuals (table 7), in one case maternal cytoplasm has an effect of growth of number of grains. When breeding line participates in hybridizing in maternal position, the F1 descendents have a number of grains bigger than reciprocals.

The effect of interactions between maternal cytoplasm and nuclear genes (table 8) is demonstrated by differences between direct and reciprocal hybrids, the number of positive and negative interactions being closely equal.

\section{CONCLUSIONS}

1 The variety Fundulea 29 has a good general combining capacity, being an important genetic source for breeding of big number of grains /spike;

2. The report GCC/ SCC, closely to 1 , suggest the equilibrate contribution of additive and non-additive effects;

3. In this set of crosses, the additive genetic actions are not significant;

4. The genetic non-additive effects are important, like interactions between maternal cytoplasm and nuclear genes.

\section{REFERENCES}

1. Ali Y., MANZOOC A. B., AKHTER, J., MONNEVEUX, PH., LATEEF Z. (2008): Genetic variability, association and diversity studies in wheat (Triticum aestivum L.) germplasm. Pak. J. Bot., 40 (5), 2087-2097.

2. BOTEZAN V., MOLDOVAN V., MOLDOVAN M. (1982): Rezultate privind ameliorarea graului in Transilvania. SCA Turda- Contributii ale cercetarii stiintifice la dezvoltarea agriculturii. Red. Prop. Agr., Bucuresti, 23-64.

3. CABULEA I. (1983): Unele aspecte statistice ale analizei genetice a capacitatii de productie. Probl. Gen. teor. Aplic. XV, 1, 31-49.

4. CEAPOIU N. (1983): Bazele genetice ale ameliorarii capacitatii de productie a plantelor agricole. Probl. Gen. teor. Aplic. XV, 1, 5-18.

5. GIURA A., SAULESCU N.N. (1996): Identificarea cromozomilor implicate in ereditatea dimensiunilor boabelor la un genotip de grau cu boabe mari. Cercet. Genet. Veget. Anim., IV, 43-48.

6. IOAN I. (1998): Capacitatea combinativa a unor genotipuri de grau comun de toamna. Cercet. Agr. Moldova, ZZZI, 1-2, 25-30.

7. IOAN I. (2004): Cercetari privind conditionarea genetica a unor caractere cantitative la grau. Cercet. Genet. Veget. Anim., VII, 123-138.

8. MADOSA E., CIULCA S., NEDELEA G. (1999): Aspecte privind ereditatea numarului de boabe din spic la grau. Biotehn. Biodiv. Ed. Agroprint, III, 5-8.

9. SAADALA M.M. (1994): Response to early-generation selection for yield and yield components in wheat. Cer. Res. Comm., 22,3, 187-193.

10. SAULESCU N.N. (1975): Metode de ameliorare a capacitatii de productie la plantele autogame. Probl. Genet. Teor. Aplic., VII, 5, 353-360.

11. SUTKA J. (1986): Genetics and physiology division. Research results Agr. Res. Inst. Hungarian Acad. Sc., 1981-1985. Ed. L. Balla, Martonvasar, 17-34.

12. ZAMA E., GASPAR I. (1998): Reactia unor soiuri de grau la stresul climatic din anul 1996. Cercet. Agr. Mold., XXXI, 1-2, 31-37. 